cially from stakeholders like international organisations and domestic political leaders that sometime exert generally unhealthy pressure on them, is also hinted.

Finally, there are a few words on some secondary issues with the book before the recommendation. On page 74 of the book, the first sentence of the first indented paragraph seems problematic, and the penultimate sentence on page 10 contains a grammatical error. There are also some typographical errors in the book (e.g. see p. 16 - line 2; p. 49 - penultimate line; p. 59 - line 11; p. 70 - line 18; and p. 97 - line 4). Perhaps a bit distracting, none of these seriously affects the clarity of the relevant arguments in this timely and elegantly written piece. Hence, I will highly recommend this book to academics working in the field of Humanities and Social Sciences (chiefly, legal scholars (especially socio-legal researchers), economists and political scientists), government officials and policymakers (national and international), donor and international financial entities, as well as journalists. And written in a largely accessible and non-technical manner, the book will be a useful addition to the library of all individuals broadly interested in the (measurement of the) realities of development within the African continent and its relations with international donor and financial entities.

Uzuazo Etemire, Glasgow

\title{
Andrea Lollini
}

\section{Constitutionalism and Transitional Justice in South Africa} Human Rights in Context, Volume 5

Berghahn Books, New York, 2011, 240 pages, $€ 58.99$ (hardcopy), ISBN:

978-1-84545-764-8 (hardcopy)

Andrea Lollini's book Constitutionalism and Transitional Justice in South Africa is the fifth volume in the series "Human Rights in Context".

The topic of Lollini's well-balanced book might be at first sight a bit general but the various political and legal changes in South Africa are just too tempting for any serious legal comparativist to abstain from.

And rightfully so: massive disruptions in nations such as the post-apartheid era in South Africa and their impact on society because of a new "Wertesystem" (system of values) introduced almost over night are still too little researched. So Lollini's analysis is another attempt to catch up with legal reality in South Africa and to categorize it aptly pursuant to Western comparative methodology.

The book is divided into two parts (Part I: "The Constitution-Making Process and Procedure", p. 17 et seq.; Part II: "The Constituent Role of the Truth and Reconciliation Commission", p. 93 et seq.) each of which consist of two chapters.

The first part describes South Africa's transition from apartheid to democracy, focusing on the establishment of the new constitutional order. Lollini thereby distinguishes deliberately between "constituent facts" and "constituent acts" (Chapter 1 "Constituent Facts", p. 19 et 
seq.; and Chapter 2 "Constituent Acts", p. 49 et seq.). These facts (social, political and military) and acts (legal and constitutional) formed together the constitution-making process and procedure in South Africa according to Lollini's methodical distinction.

In the second part (Chapter 3 "The Constitutional Suspension of a Strictly Criminal Approach", p. 95 et seq.) Lollini contrasts the approaches taken by the Truth and Reconciliation Commission of South Africa (hereinafter "TRC") with the post-conflict justice in Europe (p. 128 et seq.) and takes "notes" on post-conflict justice and political transitions outside Europe (p. 132 et seq.). Certainly it is impossible to find a complete account of the approaches taking in transitional justice cases within and outside of Europe but Lollini gives a good general overview with as many details as necessary. He further (Chapter 4 "Confession as a Strictly Constituent Act", p. 152 et seq.) analyses the role of the TRC in the new constitutional order of South Africa and underlines its "constituent function" within this context.

Lollini concludes (p. 177 et seq.) that the TRC can be regarded as a "constitutional and legal device" forming the new constitutional order of South Africa and law. Consequently, transitional justice applied by South Africa can be seen as part of its constitution-making process and procedure.

The remarkable fact about transitional justice in South Africa is indeed the work of the TRC which Lollini rightly points out. So it is at the same time an account of the uniqueness of South Africa's process of transition from apartheid to a country based on the rule of law for everyone. The current constitutionalism would simply not exist without the TRC's careful process of storytelling and granting amnesty guided by its charismatic chairman, Archbishop Desmond Tutu. The basic Christian approach of forgiveness as applied by the TRC in overcoming the atrocities during the apartheid years coupled with a procedure based on "ubun$t u$ " is certainly admirable but cannot be transplanted to other countries in transition.

Lollini's book is therefore a worthwhile add-on to the existing scholarly writings on politico-historical and legal description of South Africa's transition from the apartheid regime to the rule-of-law democracy and the process of its constitution-making with a particular focus on the role of the TRC. The book can primarily be recommended to academics - lawyers, political scientists or historians - interested in formal (state applied) transitional justice processes and constitution-making in countries in transition.

In conclusion, Lollini provides a well-researched and interdisciplinary overview of the difficult socio-political issues and history that has shaped nowadays constitutional reality in South Africa. It is hoped that many more books like his will be written to highlight the peculiar transformation processes in transitional democracies in South Africa and elsewhere, e.g. postcommunist states, concentrating on the input of transitional justice in constitution-making processes and procedures.

Inga Švarca, Heidelberg 